\title{
Airspace Capacity Analysis of Adisutjipto Airport
}

\author{
Aprinia Kusumaningsih ${ }^{1, *}$, Dewanti Dewanti' ${ }^{2}$ Imam Muthohar $^{3}$ \\ ${ }_{1,2,3}$ Departemen Teknik Sipil dan Lingkungan, Universitas Gadjah Mada \\ Email Korespondensi : " aprinia@mail.ugm.ac.id
}

Received: 2 Mei 2020; Accepted : 14 Mei 2020; Published : 1 November 2020

\begin{abstract}
ABSTRAK
Keterlambatan operasi penerbangan terjadi jika ada tundaan di darat ataupun wilayah udara. Hal tersebut disebabkan apabila permintaan lalu lintas penerbangan melebihi dari kapasitas yang tersedia. Penelitian ini bertujuan untuk menganalisis kapasitas ruang udara berdasarkan beban kerja Pemandu Lalu Lintas Penerbangan/ Air Traffic Controller (ATC) guna mendukung keselamatan, kelancaran, dan keteraturan operasi penerbangan yang menjadi tanggung jawab personil ATC. Data primer pada penelitian ini dikumpulkan melalui pengamatan kegiatan yang dilakukan oleh ATC saat memberikan pelayanan pada suatu sektor ruang udara selama 1 jam saat jam puncak dalam kurun waktu 30 hari. Data sekunder yang diperlukan untuk mendukung analisis yaitu terkait jumlah penerbangan saat jam puncak, kondisi cuaca, dan rencana penerbangan. Metode analisis yang digunakan untuk menentukan kapasitas ruang udara adalah Pessimistic Sector Capacity. Hasil penelitian menunjukkan kapasitas teoritis sebanyak 31 pesawat per jam dan kapasitas praktis 25 pesawat per jam dengan waktu kerja petugas ATC adalah 33 menit yang termasuk dalam kategori beban kerja berat. Kata Kunci: Pemandu Lalu Lintas Penerbangan, Beban Kerja, Kapasitas Ruang Udara, Pessimistic Sector Capacity
\end{abstract}

\section{ABSTRACT}

Flight operation delays occur if there are delays both on the ground and in the airspace. It happened while the demand for air traffic exceeded the available capacity. The aim of the study is to analyse the airspace capacity based on Air Traffic Controller's workload to support safety, expeditious, and orderly flow of air traffic which are the responsibility of the ATC. Primary data in this analysis were obtained by observing the activities conducted by ATC when delivering services to the airspace sector for 1 hour during peak hours within 30 days. The secondary detailed used to help the study relate to the amount of flight during peak hours, weather conditions, and flight plans. The analytical method used to determine the airspace capacity shall be the Pessimistic Sector Capacity. The result indicated a theoretical capacity of 31 aircraft per hour and practical capacity of 25 aircraft per hour with ATC personnel working time of 33 minutes being included in the heavy load category.

Keywords: Air Traffic Controller (ATC), Workload, Airspace Capacity, Pessimistic Sector Capacity

\section{PENGANTAR}

Yogyakarta sebagai salah satu kota destinasi wisata di Indonesia saat ini sudah memiliki 2 bandar udara, yaitu Bandar Udara Adisutjipto dan Bandar Udara Yogyakarta International Airport. Runway di Bandar Udara Yogyakarta International Airport memiliki panjang $3.250 \mathrm{~m}$ sehingga mampu didarati pesawat berbadan lebar (wide body). Oleh karena itu pemerintah berharap dengan beroperasinya Bandar Udara Yogyakarta International Airport mampu menarik maskapai asing untuk masuk ke Yogyakarta. Penerbangan pertama dilayani pada bulan Mei 2019, namun perusahan angkutan udara niaga berjadwal mengajukan ijin rute baru dikarenakan slot penerbangan yang ada di Bandar Udara Adisutjipto belum seluruhnya dipindahkan.

Navigasi penerbangan pada kedua bandar udara di Yogyakarta berada dibawah tanggung jawab Perum LPPNPI Cabang Yogyakarta. Pelayanan navigasi yang diberikan mulai dari Aerodrome Control Tower (TWR) hingga Approach Control Surveillance (APP). Unit TWR terdapat pada masing-masing bandar udara yang bertugas melayani pesawat pada fase taxi, take off, dan landing, sedangkan unit APP bertanggung jawab memberikan pelayanan pemanduan termasuk pelayanan informasi penerbangan dan pelayanan kesiagaan kepada pesawat udara yang berasal dari atau menuju ke Bandar Udara Adisutjipto, pesawat udara yang beroperasi di koridor, daerah pelatihan (training area), dan ruang udara terkendali militer (Military Control Airspace/ MCA) atau bisa disebut juga dengan Terminal Control Area (TMA).

Bandar Udara Adisutjipto berstatus enclave civil dan masih menjadi bandar udara utama di Yogyakarta ketika bandar udara baru belum sepenuhnya beroperasi. Penundaan penerbangan sering terjadi di Bandar Udara Adisutjipto, baik penundaan di darat (ground delay) maupun di udara (air delay). Tingkat $O n$ Time Performance (OTP) di Bandar Udara Adisujipto termasuk yang paling rendah jika dibandingkan bandar 
udara lainnya [1]. Penundaan penerbangan terjadi ketika permintaan lalu lintas mencapai atau melebihi kapasitas yang tersedia [2]. Wilayah udara yang memiliki kepadatan arus lalu lintas penerbangan yang tinggi, disarankan untuk mengukur kapasitas yang lebih aman didasarkan pada beban kerja ATC saat mengendalikan lalu lintas penerbangan dikarenakan beban kerja ATC berhubungan erat dengan kapasitas ruang udara, sehingga batasan beban kerja ATC dapat menentukan kapasitas ruang udara. [3]. Demi menjaga keselamatan penerbangan terdapat hal yang harus diperhatikan yaitu menjaga beban kerja ATC tidak terlalu tinggi dan tidak terlalu rendah sebab kedua kondisi tersebut dapat memicu ATC melakukan kesalahan, khususnya yang memiliki beban kerja tinggi [4].

Sehubungan dengan permasalahan tersebut, untuk menjamin keselamatan, kelancaran, dan keteraturan operasi penerbangan khususnya di wilayah udara Yogyakarta maka perlu dilakukan analisis kapasitas ruang udara agar dapat dijadikan baseline untuk peningkatan kapasitas kedepannya dalam menghadapi demand yang terus bertambah dan juga dapat melindungi ATC dari kelebihan beban kerja. Terkait dengan perhitungan beban kerja ATC yang dapat digunakan untuk menentukan kapasitas ruang udara, Perum LPPNPI menerbitkan pedoman perhitungan kapasitas ruang udara yang telah disesuaikan dengan kondisi lalu lintas penerbangan di Indonesia. Pedoman tersebut dituangkan dalam KP 265 Tahun 2017 yang digunakan sebagai dasar perhitungan kapasitas ruang udara pada Unit APP dan Unit TMA melalui analisis beban kerja ATC dengan metode Pessimistic Sector Capacity [5].

\section{METODE PENELITIAN}

Penelitian ini dilakukan di Unit APP Perum LPPNPI Cabang Yogyakarta yang berlokasi di komplek Bandar Udara Adisutjipto pada bulan Desember 2019 s/d Januari 2020 ketika operasional penerbangan belum dipindahkan ke bandar udara baru. Data primer dikumpulkan melalui pengamatan kegiatan yang dilakukan oleh ATC saat memberikan pelayanan terhadap pesawat udara pada periode jam puncak, yaitu pukul 08.00-11.00 WIB selama 30 hari. Kegiatan yang diamati antara lain: kegiatan rutin, monitoring perubahan ketinggian, dan monitoring konflik antar pesawat [6]. Data sekunder untuk mendukung proses analisis yaitu jumlah pergerakan pesawat saat jam puncak, kondisi cuaca, dan rencana penerbangan.

Kapasitas ruang udara dihitung berdasarkan beban kerja ATC sesuai dengan peraturan dalam KP 265 Tahun 2017. Penentuan beban kerja dihitung dengan metode Pessimistic Sector Capacity, selanjutnya untuk memperoleh nilai kapasitas ruang udara dilakukan analisis regresi linier sederhana dengan jumlah pesawat yang dilayani selama jam puncak.

\subsection{Teknik Sampling}

Teknik sampling adalah cara pengambilan sampel dari suatu populasi untuk dijadikan objek dalam suatu analisis yang merepresentasikan kondisi lalu lintas pada suatu ruang udara. Formula perhitungan sampel sebagai berikut [7].

$$
\begin{array}{r}
n=\frac{Z_{a / 2}^{2} \cdot p \cdot q \cdot N}{\varepsilon^{2}(N-1)+Z_{a / 2}^{2} \cdot p \cdot q} \\
\mathrm{p}=\frac{x}{N} \text { jumlah sektor }
\end{array}
$$

keterangan:

n : jumlah sampel, jika $\mathrm{n}<30$ maka digenapkan menjadi 30

$Z_{a / 2} \quad$ : nilai derajat kepercayaan (95\%) dengan nilai kritis adalah 1.96

$\mathrm{p} \quad$ : porsi keterlibatan individu dalam suatu grup

$\mathrm{q} \quad$ : porsi ketidakterlibatan individu dalam suatu grup $(\mathrm{q}=1-\mathrm{p})$

$\mathrm{N} \quad$ : jumlah populasi

$\varepsilon \quad$ : error yang diijinkan

$\mathrm{x} \quad$ : jumlah shift dalam 1 hari

\subsection{Teknik Perhitungan}

Perhitungan beban kerja ATC dengan metode Pessimistic Sector Capacity seperti yang tercantum dalam KP 265 Tahun 2017 yaitu dengan cara menjumlahkan semua frekuensi dan durasi pada masing-masing kegiatan/ task. Berikut ini formula yang digunakan untuk menghitung beban kerja.

$\mathrm{WL}=t_{F 1} * O_{F 1}+t_{C n f} * O_{C n f}+t_{C 1} * O_{C 1}$

keterangan:

WL : Workload/beban kerja (menit)

$t_{F 1} \quad$ : Durasi melakukan kegiatan rutin (detik)

$O_{F 1} \quad$ : Banyaknya kegiatan rutin yang dilakukan (kali/ jam) 
$t_{C n f} \quad$ : Durasi melakukan monitoring perubahan ketinggian (detik)

$O_{C n f} \quad$ : Banyaknya perubahan ketinggian yang diberikan (kali/jam)

$t_{C 1} \quad$ : Durasi menyelesaikan konflik (detik)

$O_{C 1} \quad$ : Banyak konflik yang terjadi (kali/ jam)

Berdasarkan hasil perhitungan dapat diketahui kategori beban kerja masing-masing petugas ATC. Kategorisasi beban kerja ditetapkan oleh Eurocontrol berdasarkan penelitian yang sudah dilakukan, dan dijadikan sebagai dasar dalam penilaian beban kerja ATC. Kategorisasi beban kerja yang dimaksud dapat dilihat pada Tabel 1 .

Tabel 1. Kriteria Beban Kerja ATC

(Sumber: Eurocontrol Experimental Centre (EEC) Note No.21/03)

\begin{tabular}{ccc}
\hline Batasan & Interpretasi & Waktu Kerja Selama 1 Jam \\
& & \\
\hline$>70 \%$ & Overload & $>42$ menit \\
$54 \%-69 \%$ & Heavy Load & $32-41$ menit \\
$30 \%-53 \%$ & Medium Load & $18-31$ menit \\
$18 \%-29 \%$ & Light Load & $11-17$ menit \\
$0 \%-17 \%$ & Very Light Load & $0-10$ menit \\
\hline
\end{tabular}

Batasan $70 \%$ ditetapkan melalui beberapa proses studi dengan simulasi real-time yang dilakukan oleh Eurocontrol Experimental Centre. Tiga puluh persen (30\%) mewakili kegiatan yang tidak dapat diperhitungkan secara langsung, misalnya melakukan scanning terhadap traffic pada layar radar secara menyeluruh. Kapasitas sektor teoritis tercapai ketika beban kerja ATC mencapai $70 \%$ dari waktu kerja, yaitu 42 menit dalam 1 jam [8].

\subsection{Analisis Regresi Linear}

Analisis regresi linear adalah teknik statistika untuk membuat model dan menyelidiki pengaruh antara 1 atau beberapa variabel bebas (independent variables) terhadap 1 variabel respon (dependent variable). Fungsi persamaan regresi selain untuk memprediksi nilai dependent variable (Y) juga dapat digunakan untuk mengetahui arah dan besarnya pengaruh independent variable (X) terhadap dependent variable (Y) [9]. Pada suatu analisis regresi linear perlu dilakukan pengujian agar dapat diketahui apakah model regresi tersebut merupakan model regresi yang baik atau tidak [10]. Pengujian yang dilakukan sebagai berikut.

a. Uji normalitas

Tujuan uji normalitas adalah untuk menguji apakah dalam sebuah model regresi, variabel terikat dan variabel bebas atau keduanya mempunyai distribusi normal atau tidak. Model regresi yang baik adalah distribusi data normal atau mendekati normal.

b. Uji linearitas

Uji linearitas dilakukan dengan tujuan untuk mengetahui apakah variabel-variabel penelitian memiliki korelasi yang signifikan.

c. Uji Heteroskedastisitas

Uji heteroskedastisitas dilakukan untuk menguji apakah dalam sebuah model regresi terjadi ketidaksamaan varians residual dari satu pengamatan ke pengamatan yang lain tetap.

\subsection{Uji Hipotesis}

Hipotesis merupakan jawaban sementara terhadap rumusan masalah penelitian. Kebenaran suatu hipotesis harus dibuktikan melalui data yang terkumpul [11]. Uji hipotesis pada penelitian ini adalah sebagai berikut.

a. Penentuan hipotesis

b. Penentuan batas atau tingkat kemaknaan (level of significance)

c. Penentuan uji statistik yang sesuai

d. Penghitungan uji statistik

e. Pengambilan keputusan

\section{HASIL DAN PEMBAHASAN}

\subsection{Gambaran Umum Ruang Udara Yogyakarta}

Ruang udara Yogyakarta masuk ke dalam klasifikasi Kelas C, yaitu ruang udara dimana penerbangan yang diijinkan adalah penerbangan Instrument Flight Rules (IFR) dan Visual Flight Rules (VFR). Semua penerbangan diberikan pelayanan ATC serta harus ada separasi antara IFR-IFR, IFR-VFR, 
dan VFR-IFR. VFR menerima traffic information mengenai adanya VFR lainnya [12]. Gambaran ruang udara Yogyakarta dapat dilihat pada Gambar 1 dan Gambar 2.

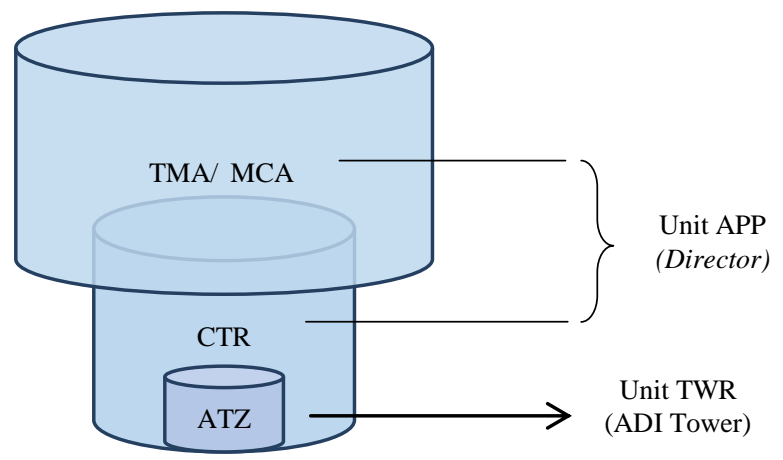

Gambar 1. Pembagian Ruang Udara Yogyakarta dan Unit yang Menangani

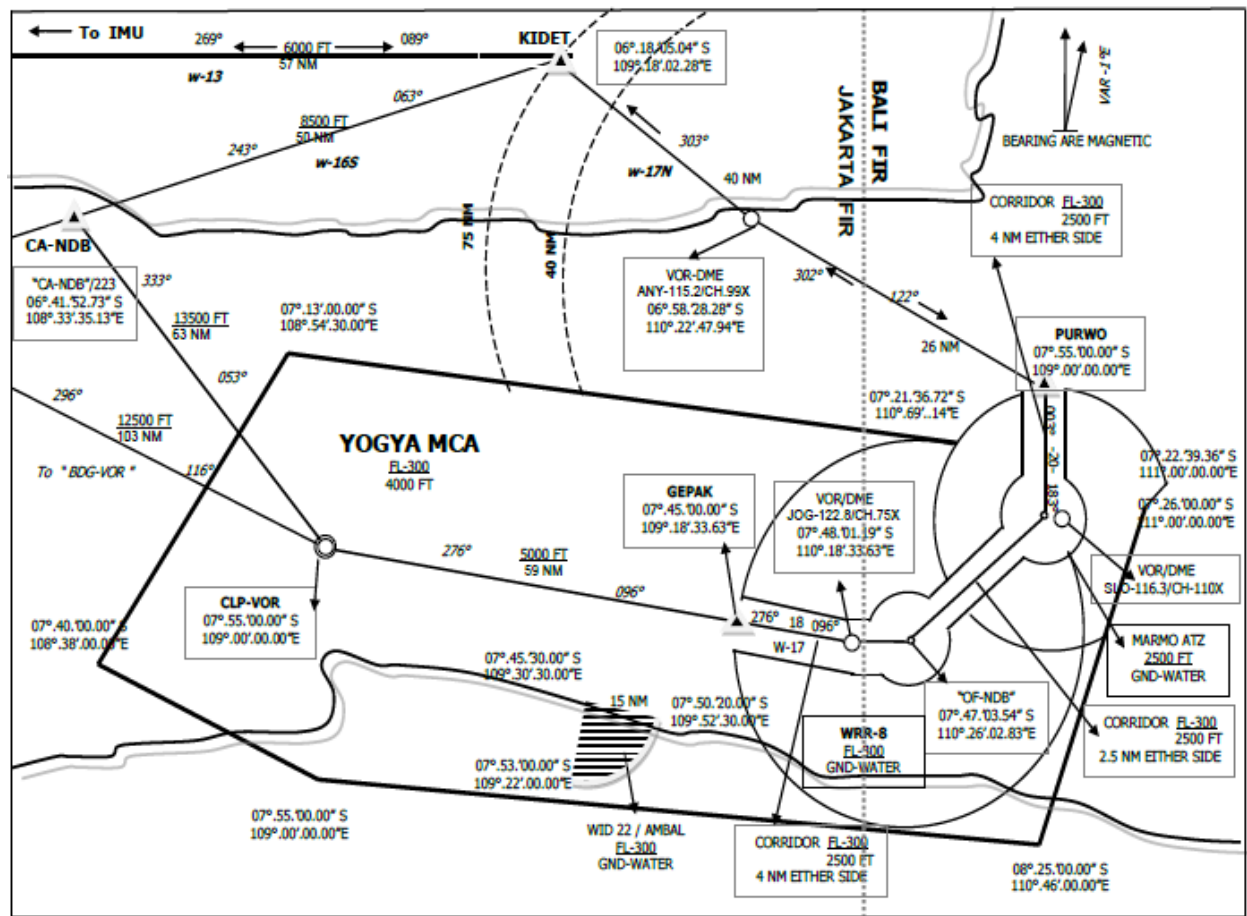

Gambar 2. Ruang Udara Yogyakarta

(Sumber: Perum LPPNPI Cabang Yogyakarta, 2019)

Ruang udara Yogyakarta dibagi atas 2 sektor, yaitu Control Area (CTR) dan Terminal Control Area (TMA). Di dalam CTR terdapat Aerodrome Traffic Zone (ATZ) sedangkan di dalam TMA terdapat ruang udara terkendali militer/ Military Control Area (MCA). Pesawat yang berada di ATZ dikendalikan oleh Unit TWR dan pesawat yang terbang di MCA dikendalikan oleh Unit APP. Lalu lintas penerbangan yang berada di dalam MCA tentu bukan hanya pesawat yang akan mendarat di Bandar Udara Adisutjipto namun terdapat pula pesawat yang terbang melintas (overflying), seperti pada Tabel 2.

Tabel 2. Rute Penerbangan Lintas (Overflying)

(Sumber: Perum LPPNPI Cabang Yogyakarta, 2019)

\begin{tabular}{|c|c|c|}
\hline No & $\begin{array}{rr}\text { Rute } \\
\end{array}$ & Keterangan \\
\hline 1 & Solo - Jakarta (Soekarno Hatta) & pp \\
\hline 2 & Solo - Jakarta (Halim) & $\mathrm{pp}$ \\
\hline 3 & Solo - Banjarmasin & $\mathrm{pp}$ \\
\hline 4 & Solo - Denpasar & $\mathrm{pp}$ \\
\hline 5 & Solo - Bandung & $\mathrm{pp}$ \\
\hline 6 & Solo - Padang & $\mathrm{pp}$ \\
\hline 7 & Yogyakarta (Kulonprogo) - Balikpapan & $\mathrm{pp}$ \\
\hline
\end{tabular}




\begin{tabular}{clc}
8 & Yogyakarta (Kulonprogo) - Palangkaraya & $\mathrm{pp}$ \\
9 & Yogyakarta (Kulonprogo) - Jakarta (Soekarno Hatta) & $\mathrm{pp}$ \\
10 & Yogyakarta (Kulonprogo) - Jakarta (Halim) & $\mathrm{pp}$ \\
11 & Yogyakarta (Kulonprogo) - Banjarmasin & $\mathrm{pp}$ \\
\hline
\end{tabular}

Ketika operasional penerbangan dipindahkan ke bandar udara baru, maka tidak merubah tanggung jawab dan beban kerja ATC di Unit APP dikarenakan batas vertikal Unit APP sampai ketinggian 30.000 kaki dan batas lateral sejauh 20 NM berpusat pada "SO" NDB. Terlepas nantinya Unit APP yang saat ini berada di komplek Adisutjipto ikut dipindahkan ke bandara baru atau tidak. Lain halnya dengan tanggung jawab ATC yang bekerja di Unit TWR, jika operasional penerbangan di Bandar Udara Adisutjipto dipindahkan ke bandar udara baru maka tanggung jawab petugas ATC di TWR Adisutjipto hanya mengendalikan pesawat militer dan pesawat komersil bertipe baling-baling (propeller).

\subsection{Perhitungan Kapasitas Ruang Udara}

Berdasarkan perhitungan sampel dengan persamaan (1) dan (2), diperoleh jumlah ATC yang akan disurvei selama melakukan pemanduan berjumlah 31 personil. Selanjutnya dilakukan pengukuran jumlah dan frekuensi pada masing-masing kegiatan selama proses pemanduan saat jam puncak. Perhitungan beban kerja dilakukan sesuai dengan persamaan (3), sehingga diperoleh hasil beban kerja ATC di Unit APP Perum LPPNPI Cabang Yogyakarta bahwa terdapat 11 personil memiliki beban kerja medium load, 17 personil memiliki beban kerja heavy load, dan 3 personil yang beban kerjanya sudah mencapai overload.

Rekapitulasi beban kerja ATC dan jumlah pesawat yang dilayani selama jam puncak dapat dilihat pada Tabel 3. Langkah selanjutnya untuk menentukan nilai kapasitas ruang udara dilakukan analisis regresi linear sederhana antara beban kerja ATC (variabel X) dengan jumlah pergerakan pesawat saat jam puncak (variabel Y).

Tabel 3. Rekapitulasi Beban Kerja Petugas ATC

\begin{tabular}{|c|c|c|c|c|c|c|}
\hline Personil & $\begin{array}{l}\text { Kegiatan } \\
\text { Rutin }\end{array}$ & $\begin{array}{l}\text { an Kerja (me } \\
\text { Perubahan } \\
\text { Ketinggian }\end{array}$ & $\begin{array}{l}\text { Konflik } \\
\text { Pesawat }\end{array}$ & $\begin{array}{l}\text { Total Beban Kerja } \\
\text { (menit) }\end{array}$ & $\begin{array}{l}\sum \text { Pesawat saat } \\
\text { yang Dilayani }\end{array}$ & $\begin{array}{c}\text { Kategori Beban } \\
\text { Kerja }\end{array}$ \\
\hline ATC 1 & 18 & 4 & 2 & 24 & 17 & Medium \\
\hline ATC 2 & 19 & 6 & 3 & 28 & 24 & Medium \\
\hline ATC 3 & 23 & 5 & 2 & 30 & 21 & Medium \\
\hline ATC 4 & 20 & 5 & 2 & 28 & 23 & Medium \\
\hline ATC 5 & 26 & 5 & 2 & 33 & 22 & Heavy \\
\hline ATC 6 & 22 & 6 & 3 & 30 & 24 & Medium \\
\hline ATC 7 & 28 & 8 & 2 & 37 & 28 & Heavy \\
\hline ATC 8 & 22 & 7 & 3 & 32 & 31 & Heavy \\
\hline ATC 9 & 24 & 6 & 2 & 32 & 25 & Heavy \\
\hline ATC 10 & 20 & 5 & 2 & 27 & 23 & Medium \\
\hline ATC 11 & 30 & 8 & 5 & 43 & 30 & Overload \\
\hline ATC 12 & 21 & 6 & 6 & 32 & 25 & Heavy \\
\hline ATC 13 & 27 & 5 & 3 & 35 & 27 & Heavy \\
\hline ATC 14 & 24 & 7 & 3 & 33 & 24 & Heavy \\
\hline ATC 15 & 31 & 7 & 4 & 42 & 29 & Overload \\
\hline ATC 16 & 31 & 8 & 2 & 40 & 28 & Heavy \\
\hline ATC 17 & 27 & 5 & 3 & 35 & 26 & Heavy \\
\hline ATC 18 & 23 & 5 & 2 & 30 & 24 & Medium \\
\hline ATC 19 & 26 & 5 & 2 & 33 & 25 & Heavy \\
\hline ATC 20 & 23 & 6 & 3 & 33 & 25 & Heavy \\
\hline ATC 21 & 23 & 4 & 2 & 28 & 22 & Medium \\
\hline ATC 22 & 17 & 4 & 2 & 22 & 17 & Medium \\
\hline ATC 23 & 30 & 8 & 5 & 42 & 31 & Overload \\
\hline ATC 24 & 30 & 9 & 2 & 41 & 28 & Heavy \\
\hline ATC 25 & 22 & 7 & 4 & 33 & 25 & Heavy \\
\hline ATC 26 & 27 & 5 & 4 & 37 & 27 & Heavy \\
\hline ATC 27 & 24 & 9 & 2 & 35 & 26 & Heavy \\
\hline ATC 28 & 23 & 5 & 2 & 29 & 22 & Medium \\
\hline ATC 29 & 27 & 5 & 3 & 35 & 27 & Heavy \\
\hline ATC 30 & 18 & 3 & 2 & 23 & 17 & Medium \\
\hline ATC 31 & 23 & 6 & 3 & 32 & 26 & Heavy \\
\hline
\end{tabular}

Hasil perhitungan beban kerja yang ditampilkan pada Tabel 3 ternyata banyaknya pesawat yang dilayani bukanlah satu-satunya faktor yang mempengaruhi beban kerja dan waktu kerja rata-rata yang dihabiskan ATC saat melakukan pemanduan selama 1 jam yaitu 33 menit. Jika banyaknya pesawat yang dilayani menjadi satu-satunya faktor yang berkontribusi mempengaruhi beban kerja, seharusnya semakin banyak jumlah pesawat yang dilayani maka beban kerja juga semakin tinggi.

Merujuk pada penelitian yang telah dilakukan [4] bahwa beban kerja ATC tidak hanya dipengaruhi oleh jumlah pesawat yang dilayani, tetapi juga perlu diperhatikan adanya faktor lain yang nantinya akan 
berpengaruh terhadap kompleksitas. Namun, perhitungan beban kerja pada penelitian ini yang mengacu pada Peraturan Direktur Jenderal Perhubungan Udara KP 265 Tahun 2017 hanya menitikberatkan pada banyaknya komunikasi yang dilakukan dengan pesawat, koordinasi yang dilakukan oleh ATC kepada adjacent unit/ asisten/ planner, banyaknya pesawat yang climb/ descend, serta banyaknya konflik antar pesawat.

Apabila beban kerja ATC sudah diketahui, maka untuk menghitung kapasitas ruang udara dilakukan analisis regresi linear sederhana. Pada analisis regresi perlu dilakukan uji asumsi klasik sebagai syarat yang harus dipenuhi untuk mengetahui apakah model regresi tersebut baik atau tidak. Uji asumsi klasik yang dilakukan pada penelitian ini, antara lain:

a. Uji normalitas

Uji statistik normalitas dalam penelitian ini yaitu uji Kolmogorov-Smirnov menggunakan aplikasi SPSS dengan taraf signifikansi $(\alpha)$ sebesar 5\%, jika signifikansi lebih dari 0,05 maka data dinyatakan berdistribusi normal. Hasil uji normalitas pada Lampiran 1 menunjukkan nilai Sig. sebesar 0,388 lebih besar dari 0,05 .

b. Uji Linearitas

Uji linearitas dilakukan untuk mengetahui apakah 2 variabel mempunyai hubungan yang linear atau tidak secara signifikan. Uji linearitas dilakukan pada taraf signifikansi $(\alpha)$ sebesar 5\%. Dua variabel mempunyai hubungan yang linear apabila signifikansi (Sig.) dari deviation from linearity lebih dari 0,05. Berdasarkan hasil uji linearitas seperti pada Lampiran 2, diperoleh nilai Sig. 0,142 lebih besar dari 0,05 .

c. Uji Heteroskedastisitas

Uji heteroskedastisitas dilakukan untuk mengetahui adanya penyimpangan dari syarat-syarat asumsi klasik pada model regresi. Didalam model regresi yang baik harus dipenuhi syarat tidak adanya heteroskedastisitas. Jika nilai signifikansi (Sig.) lebih besar dari 0,05 maka tidak terjadi gejala heteroskedastisitas. Hasil uji heteroskedastisitas pada Lampiran 3 menunjukkan bahwa Sig. sebesar 0,294 lebih besar dari 0,05.

d. Uji hipotesis

Uji Hipotesis dilakukan untuk mengetahui apakah koefisien regresi tersebut signifikan atau tidak. Tahapan dalam melakukan uji hipotesis pada penelitian ini sebagai berikut.

1) Penentuan hipotesis

$\mathrm{H}_{\mathrm{o}}$ : tidak ada pengaruh beban kerja $(\mathrm{X})$ terhadap jumlah pesawat $(\mathrm{Y})$

$\mathrm{H}_{\mathrm{a}}$ : ada pengaruh beban kerja (X) terhadap jumlah pesawat $(\mathrm{Y})$

2) Penentuan batas atau tingkat kemaknaan (level of significance)

Level of significance $(\alpha)$ pada penelitian ini adalah $5 \%$

3) Penentuan uji statistik yang sesuai

Pengujian hipotesis pada penelitian ini menggunakan uji t, dimana dasar pengambilan keputusan dalam uji t sebagai berikut.

i. Jika nilai $t_{\text {hitung }}>t_{\text {tabel }}$ maka ada pengaruh beban kerja $(X)$ terhadap jumlah pesawat $(\mathrm{Y})$;

ii. Jika nilai $t_{\text {hitung }}<\mathrm{t}_{\text {tabel }}$ maka ada tidak ada pengaruh beban kerja $(\mathrm{X})$ terhadap jumlah pesawat (Y).

4) Penghitungan uji statistik

Hasil dari perhitungan dengan SPSS pada Lampiran 4 diperoleh nilai $\mathrm{t}_{\text {hitung }}$ sebesar 9,928. Agar dapat mengetahui tingkat pengaruh antara variabel $\mathrm{X}$ dengan variabel $\mathrm{Y}$ maka perlu dibandingkan nilai $t_{\text {hitung }}$ dengan $t_{\text {tabel }}$. Penentuan nilai $t_{\text {tabel }}$ terlebih dahulu harus diketahui besaran $\alpha$ dan df (degree of freedom/ derajat kebebasan). Nilai $\alpha$ pada penelitian ini adalah 5\% atau 0,05 dengan hipotesis 2-tailed, sehingga $\alpha / 2=0,025$. Df merupakan hasil pengurangan dari jumlah sampel (n) dikurangi dengan jumlah varibel bebas (k), dan konstanta 1. Selanjutnya dapat dilihat pada distribusi $\mathrm{t}_{\text {tabel }}(0,025 ; 29)$, maka diperoleh nilai $\mathrm{t}_{\text {tabel }}=2,045$.

5) Pengambilan keputusan Berdasarkan uraian tersebut, nilai $t_{\text {hitung }} 9,928$ lebih besar $t_{\text {tabel }}$ 2,045 sehingga dapat disimpulkan bahwa $\mathrm{H}_{\mathrm{o}}$ ditolak dan $\mathrm{H}_{\mathrm{a}}$ diterima, yang artinya bahwa ada pengaruh beban kerja $(\mathrm{X})$ terhadap jumlah pesawat (Y).

Hasil persamaan dari analisis regresi pada penelitian ini dapat dilihat pada Lampiran 4, sebagai berikut.

$$
Y=5,495+0,591 X
$$

Kapasitas teoritis (maksimum) tercapai saat beban kerja ATC mencapai 70\% dari waktu kerja yaitu 42 menit dalam 1 jam. Tiga puluh persen (30\%) mewakili tugas yang tidak dapat diperhitungkan, seperti 
melakukan pemantauan traffic layar radar secara menyeluruh. Oleh karena itu, kapasitas maksimum ruang udara Yogyakarta adalah:

$$
Y=5,495+0,591(42)=30,317 \sim 31 \text { pesawat }
$$

Unit pelayanan lalu lintas penerbangan tidak dapat beroperasi dengan kapasitas secara maksimum dikarenakan pada saat tertentu akan terdapat beberapa variabel yang dapat mengurangi kapasitas sehingga disarankan untuk mengambil nilai $80 \%$ sampai dengan $90 \%$ dari nilai total kapasitas, atau disebut dengan kapasitas praktis untuk selanjutnya dijadikan sebagai kapasitas yang dipublikasikan/ declared capacity [13]. Jika declared capacity diambil nilai $80 \%$ dari kapasitas maksimum maka kapasitas ruang udara Yogyakarta sebanyak 25 pesawat per jam.

Data yang diambil sesuai dengan Tabel 3, diketahui bahwa paling sedikit jumlah pesawat yang dilayani di sektor TMA Yogyakarta selama periode pengambilan data yaitu 17 pesawat per jam dan jumlah terbanyak yang dilayani dalam 1 jam adalah 31 pesawat, sementara kapasitas praktis yang tersedia berdasarkan hasil analisis yaitu 25 pesawat per jam. Dengan demikian, kondisi ruang udara Yogyakarta saat ini sudah over capacity, apabila hal tersebut dibiarkan saja maka akan berdampak pada operasi penerbangan. Dampak tersebut tidak hanya dirasakan oleh Bandar Udara Adisutjipto sebagai bandar udara utama di Yogyakarta namun juga dirasakan oleh bandar udara disekitarnya seperti Bandar Udara Adisoemarmo dan Bandar Udara Yogyakarta International Airport.

Untuk mengatasi masalah kapasitas ruang udara, langkah penting yang dapat dilakukan yaitu dengan sektorisasi. Sektorisasi dilakukan pada sektor TMA dengan cara membagi TMA menjadi 2 sektor yang memiliki kapasitas yang sama, yaitu TMA East dan TMA West. Dengan adanya pembagian sektor maka frekuensi radio yang digunakan juga berbeda sehingga dapat mengurangi beban kerja ATC dalam berkomunikasi dengan pesawat udara. Diasumsikan bahwa kapasitas ruang udara sektor TMA Yogyakarta dibagi menjadi 2 sama rata, maka jumlah pesawat yang masuk di ruang udara Yogyakarta pun juga dibagi 2. Berdasarkan data pergerakan lalu lintas penerbangan harian yang ditampilkan pada Tabel 3, dapat diketahui bahwa jumlah pesawat terbanyak saat jam puncak adalah 31 pesawat. Jumlah tersebut diasumsikan sebagai kapasitas praktis pada kedua sektor, sehingga masing-masing sektor memiliki kapasitas praktis sebanyak 16 pesawat tiap jam.

Selanjutnya, perhitungan waktu kerja ATC yang bekerja pada sektor TMA dapat dihitung dengan rumus hasil persamaan regresi berikut.

$$
\begin{gathered}
Y=5,495+0,591 X \\
X=\frac{Y-5,495}{0,591}=\frac{16-5,495}{0,591}=17,775 \sim 18 \text { menit }
\end{gathered}
$$

Kondisi saat ini yang berlangsung di Unit APP Perum LPPNPI Cabang Yogyakarta selama proses pengambilan data, ATC menghabiskan waktu bekerja rata-rata 33 menit (heavy load). Jika dilakukan sektorisasi, maka ATC akan bekerja selama 18 menit. Pengurangan beban kerja ATC dapat dihitung dengan cara berikut ini.

\section{KESIMPULAN}

$$
\% \Delta X=\frac{33-18}{33} \times 100 \%=45 \%
$$

Perhitungan kapasitas ruang udara dilakukan berdasarkan beban kerja ATC dengan metode Pessimistic Sector Capacity sesuai KP 265 Tahun 2017 yang dihitung dengan mengacu pada kegiatan yang dilakukan oleh ATC selama pemanduan. Faktor lain yang membuat suatu tugas menjadi mudah atau sulit ditangani oleh petugas ATC atau yang disebut dengan kompleksitas belum dipertimbangkan dalam perhitungan beban kerja. Faktor yang menyebabkan kompleksitas misalnya dimensi ruang udara, konfigurasi rute, dan jenis pesawat yang beroperasi.

Hasil perhitungan kapasitas ruang udara diperoleh nilai kapasitas maksimum sebanyak 31 pesawat per jam. Namun unit pelayanan lalu lintas penerbangan tidak dapat beroperasi dengan kapasitas maksimum dikarenakan pada saat tertentu akan terdapat beberapa variabel yang dapat mengurangi kapasitas sehingga diambil $80 \%$ dari nilai total kapasitas atau disebut dengan kapasitas praktis, sehingga nilai kapasitas praktis diperoleh 25 pesawat per jam. Dengan demikian, permintaan lalu lintas penerbangan di wilayah udara Yogyakarta saat ini telah melampaui batas kapasitas ruang udara (overload).

Untuk mengatasi masalah kapasitas ruang udara agar tidak overload dan menjaga beban kerja ATC berada dalam kategori medium load maka perlu dilakukan sektorisasi. Setelah sektor TMA dibagi menjadi 2 wilayah yaitu TMA East dan TMA West dengan asumsi kondisi pada kedua sektor tersebut sama, maka akan terjadi pengurangan waktu kerja ATC dari 33 menit menjadi 18 menit dengan persentase pengurangan beban kerja sebanyak $45 \%$. 


\section{DAFTAR PUSTAKA}

[1] S. Ariesta and F. Sari, “Analisis Dampak On Time Performance ( OTP ) Pada Kegiatan Transportasi Udara ( Studi pada Keterlambatan Jadwal Penerbangan di Bandar Udara Internasional,” vol. 60, no. 2, pp. 169-178, 2018.

[2] C. Çetek and R. K. Çeçen, "En-Route Airspace Capacity And Traffic Flow Enhancement Using Genetic Algorithms," Anadolu University Journal Of Science And Technology A - Applied Sciences and Engineering, vol. 18, no. 1, pp. 39-39, Mar. 2017.

[3] A. Majumdar and W. Y. Ochieng, "Factors Affecting Air Traffic Controller Workload: Multivariate Analysis Based on Simulation Modeling of Controller Workload," Transportation Research Record: Journal of the Transportation Research Board, vol. 1788, no. 1, pp. 58-69, Jan. 2002.

[4] A. Számel, I. Mudra, and G. Szabó, “Applying Airspace Capacity Estimation Models to the Airspace of Hungary,” Periodica Polytechnica Transportation Engineering, vol. 43, no. 3, pp. 120-128, 2015.

[5] Kementerian Perhubungan, "Peraturan Direktur Jenderal Perhubungan Udara No. KP 265 Tahun 2017 Tentang Standar Teknis dan Operasi Bagian 170-03 (Manual of Standard CASR Part 170-03) Pedoman Penghitungan Kapasitas Ruang Udara dan Kapasitas Landas Pacu (Airspace Capacity and Runway Capacity)”, Jakarta: Kementerian Perhubungan, 2017

[6] Airnav Indonesia, "Manual Perhitungan Kapasitas Ruang Udara”, Tangerang: Perum LPPNPI, 2015

[7] International Civil Aviation Organization, "Fourth Workshop/ Meeting of the SAM Implementation Group (SAM/IG/4) Regional Project RLA/06/901”, South America: ICAO Regional Office, 2019

[8] Eurocontrol Experimental Centre, "Pessimistic Sector Capacity Estimation EEC Note No.21/03", Prancis: Eurocontrol,2003

[9] Basuki, A.T.,and Nano, P., “Analisis Regresi dalam Penelitian Ekonomi dan Bisnis”, Jakarta: Raja Grafindo Persada, 2016

[10] Ghozali, I., "Aplikasi Analisis Multivariat dengan Program SPSS”, Semarang: Badan Penerbit Universitas Diponegoro, 2005

[11] Sugiyono, "Metode Penelitian Kuantitatif, Kualitatif dan R\&D”, Bandung: Alfabeta, 2006

[12] Airnav Indonesia, "Prosedur Operasi Standar Pelayanan Lalu Lintas Penerbangan", Yogyakarta: Perum LPPNPI Cabang Yogyakarta, 2019

[13] International Civil Aviation Organization, "Doc.9426 Air Traffic Services Planning Manual", Canada: ICAO,2005 